\title{
JALAN PANJANG PEMBERITAAN TERORISME DI INDONESIA SEJAK MASA KOLONIAL HINGGA KINI
}

\author{
John Nedy Kambang1), Rahmi Surya Dewi ${ }^{2),}$ Ernita Arief $^{3)}$ \\ 1) Magister Ilmu Komunikasi FISIP Universitas Andalas; jk.kambang@gmail.com \\ 2) Jurusan Ilmu Komunikasi FISIP Universitas Andalas; rahmi.ikom@gmail.com \\ 3) Jurusan Ilmu Komunikasi FISIP Universitas Andalas; arifernita@yahoo.co.id
}

\begin{abstract}
ABSTRAK
Media massa yang sudah ada sejak orang Eropa masuk ke Indonesia mengalami banyak perkembangan. Media cetak pertama yang diterbitkan oleh orang Eropa, Bataviasche Nouvelles hanya memuat informasi tentang pemerintahan VOC, perdagangan, hiburan, iklan lelang, dan sejarah koloni Belanda di Hindia. Juga tentang penyebaran agama Katolik dan Protestan, serta perkembangan gereja di Hindia Belanda. Dalam perkembangan selanjutnya, berbagai media massa mulai bermunculan, seperti koran dan majalah yang tidak hanya dimiliki oleh Belanda, tetapi juga dibuat oleh masyarakat adat, seperti Medan Prijaji, Otoesan Hindia dan banyak lagi lainnya. Media terus berkembang hingga saat ini. Tidak ada yang berubah dalam tujuan media, dari dulu hingga sekarang, yaitu untuk menyampaikan informasi. Namun cara penyampaian dan isi beritanya tampak jauh berbeda. Salah satunya dalam penyampaian berita tentang perang dan terorisme. Pada zaman Belanda, berita tentang perang dan terorisme tidak diberitakan dengan jelas. Sementara itu, saat ini media massa seolah terbagi menjadi dua fungsi, sebagai pelindung bagi aparatur pemerintah, dan sebagai penyebarluasan. Dalam pemberitaan terorisme, media saat ini sangat terbuka dalam memberitakannya. Penangkapan anggota terorisme di mana penembakan itu juga disiarkan secara langsung. Telah terjadi pergeseran pola penyampaian media dari era kolonial Belanda ke era Reformasi, terutama pada isu-isu sensitif seperti terorisme. Artikel ini menggunakan kombinasi pendekatan naratif dengan pendekatan historis, dalam melihat perkembangan media massa dalam pemberitaan terorisme dari jaman penjajahan Belanda hingga era reformasi saat ini. Kecenderungan penelitian ini bersifat historis, bercampur dengan narasi yang dibangun oleh tokoh-tokoh yang menjadi sumber informasi. Metodologi yang digunakan dalam artikel ini menggunakan studi literatur berupa arsip media massa sebagai sumber datanya, dan dilengkapi dengan wawancara dari pakar terorisme sebagai sumber untuk memperkuat analisis.
\end{abstract}

Kata Kunci: transformasi, media, teroris

\begin{abstract}
The mass media, which has existed since Europeans entered Indonesia, has undergone many developments. The first printed media published by Europeans, Bataviasche Nouvelles, only contained information about the VOC government, trade, entertainment, auction advertisements and the history of the Dutch colony in the Indies. Also about the spread of Catholicism and Protestantism, and the development of the church in the Indies. In subsequent developments, various mass media began to appear, such as newspapers and magazines which were not only owned by the Dutch, but also made by indigenous people, such as Medan Prijaji, Otoesan Hindia and many others. The media continues to evolve to this day. Nothing has changed in the purpose of the media, from past to present, namely to convey information. However, the method of delivery and the content of the news seems much different. One of them is in delivering news about war and terrorism. During the Dutch era, news about war and terrorism was not reported clearly. Meanwhile, today the mass media seems to be divided into two functions, as a protector for government officials, and as a propagator. In reporting on terrorism, the media today are very open in reporting it. The arrests of members of terrorism in which the shooting were also broadcast live. There has been a shift in the pattern of media delivery from the Dutch colonial era to the Reformation Era, especially on sensitive issues such as terrorism. This article uses a combination of a narrative approach with a historical approach, in observing the development of the mass media in reporting on terrorism from the Dutch colonial era to the reform era today. The tendency of this research
\end{abstract}


is historical, mixed with narratives built by figures who become sources of information. The methodology used in this article uses literature studies in the form of mass media archives as a data source, and is complemented by interviews from terrorism experts as sources to strengthen the analysis.

Keyword: Transformation, Media, Terrorism

\section{PENDAHULUAN}

Kolonialisme Belanda di Indonesia tidak hanya semata-mata menguasai beberapa sektor pertumbuhan yang ada di bumi Indonesia. Sistem ketatanan negara harus sesuai dengan sistem kolonial yang berlaku di pemerintahan Belanda, termasuk untuk tatanan media massa. Keberadaan media massa telah memiliki peran yang penting bagi pemerintah kolonial maupun rakyat Indonesia. Pemerintah Hindia Belanda memanfaatkan media massa sebagai alat untuk menyampaikan informasi, berita, bahkan propaganda, sekaligus juga sarana komunikasi antar sesama orang Eropa maupun dengan rakyat jajahannya.

Pada awal kedatangannya hingga kemudian membentuk VOC, Belanda memanfaatkan media massa sebagai alat komunikasi antar sesama pedagang yang tergabung dalam VOC. Media-meda massa di awal masa penjajahan ini adalah media cetak, yaitu surat kabar yang dikenal dengan nama Bataviasche Nouvelless. Diterbitkan oleh Jan Erdmans Jordens pertama kali pada 7 Agustus 1744 di Batavia, namun baru medapat izin edar pada 9 Februari 1745. Surat kabar ini terbit sekali dalam seminggu dengan jumlah halaman sebanyak empat lembar folio yang ditulis tangan. Bataviasche Nouvelless memuat mengenai informasi-informasi pemerintahan VOC, perdagangan, iklan kaleng, hiburan, serta kisah-kisah perjalanan atau sejarah koloni Belanda di Hindia Belanda.

Bataviase Nouvelles sempat berhenti beredar pada tahun 1746 atas perintah para Direktur VOC yang cemas melihat pers berkembang di Hindia Belanda. Akan tetapi pada bulan Nopember 1809 surat kabar ini bangkit kembali. Pada pemunculan kedua ini, bentuknya lebih kecil dan hanya memuat adpertensi. Orang Melayu dan Bumi putera menyebutnya dengan nama Surat Lelang, sedangkan Belanda menyebutnya VenduNieuws. Sementara itu pada masa pemerintahan Daendels diberlakukan peraturan khusus yang menyatakan bahwa redaktur Bataviaasche Nouvelles wajib untuk menempatkan kepentingan pemerintah dalam surat kabarnya. Selain peraturan tersebut Daendels juga mengubah nama Bataviaasche Nouvelles menjadi Bataviaasche Koloniale Courant.

Pada perkembangan selanjutnya, media massa di Hindia Belanda masih berupa media cetak dalam bentuk surat kabar atau koran. Selain Bataviaasche Nouvelles, juga muncul koran-koran lain yang berisikan berita, hiburan, serta kritik untuk pejabat pemerintahan. Seperti pada tahun 1903, dimana pers mulai menghangat, banyak petinggi pemerintahan yang menuliskan kritik terhadap pejabat pemerintahan yang menjadi atasannya. 
Pertumbuhan surat kabar sangat masif hampir diseluruh wilayah Indonesia, baik surat kabar lokal yang hanya beredar di wilayah tertentu, maupun surat kabar nasional yang beredar di seluruh wilayah Indonesia. Menurut Benedict Anderson dalam tulisan pengantarnya di buku berjudul Indonesia dalam Bara Api, menyebutkan bahwa "Koran mulai tumbuh di hampir setiap kota jang berarti, mirip tjendawan dimusim hudjan. Timbullah djagoan2 masa media pertama di Hindia Belanda, termasuk diantaranya Mas Tirto, F. Wiggers, H. Kommer, Tio Ie Soei, Marah Sutan, G. Franscis, Soewardi Soerjadingrat, ter Haar, Mas Marco, Kwee Kek Beng, dan J.H. end F.D.J Pangemanann pakai dua 'n'."'

Kemunculan media ini dilatarbelakangi oleh kesadaran sebagian pribumi bahwa media memiliki peranan yang penting dalam kehidupan masyarakat, yaitu sebagai penyampai informasi dan juga dapat dimanfaatkan untuk menggugah rasa nasionalisme rakyat sebagai rakyat terjajah. Hal ini seperti yang ditulis Medan Prijaji dibawah judul korannya yang berbunyi: Orgaan bagi bangsa jang terperintah di Hindia Olanda tempat membuka suaranja.

Pertumbuhan surat kabar pribumi yang masif bahkan membuat kolonial Belanda sedikit takut hingga mengeluarkan UU pers, dengan harapan dapat menekan pertumbuhan pers pribumi. Meski media yang berkembang pada awal abad 20 sebagian telah mendapat izin dari pemerintah Hindia Belanda, namun ada ketentuan khusus dimana informasi yang disampaikan tidak bertentangan dengan kebijakan pemerintah Hindia Belanda. Sedangkan media yang digunakan untuk menggugah rasa nasionalisme rakyat, biasanya disebarkan secara sembunyi-sembunyi diantara kalangan rakyat. Hal ini terus berkembang seiring bertambahnya pengetahuan akan dunia serta pendidikan rakyat pribumi sepanjang perjalanan bangsa Belanda di Indonesia. Termasuk dengan perkembangan pemberitaan ekstrem, seperti isu terorisme.

Setelah Indonesia merdeka pada tanggal 17 Agustus 1945, Indonesia mengalami masa pemulihan keamanan yang panjang. Tidak hanya agresi dari pemerintahan kolonial Belanda yang ingin mengembalikan kekuasaannya saja yang dihadapi oleh Indonesia. tetapi pemberontakan dan gerakan separatis dari bangsa Indonesia sendiri juga menjadi permasalahan yang dihadapi Indonesia bahkan hingga tahun 1967. Dalam rentang waktu yang panjang tersebut, perkembangan media massa berjalan lambat. Hingga terbentuknya Orde Baru pada tahun 1967, bukannya menjadi lebih baik, media massa justru berkembang ke arah yang memiriskan. Pemerintahan orde baru melakukan komtrol yang ketat terhadap media massa. Media massa yang dianggap melakukan pemberitaan mendiskreditkan pemerintah, akan langsung dibredel. Pemerintah seolah menutup mata dan telinga rakyatnya untuk bisa mengetahui perkembangan apa saja yang terjadi dalam pemerintahan.

Tanpa disadari, pada masa Orde Baru, semua yang terlihat diluar pemerintahan begitu baik dan berjalan pada jalur yang adil. Hal ini terjadi karena pemerintah yang 
telah mengatur bola kehidupan rakyat Indonesia, sehingga apa yang terlihat diluar seperti sempurna dan berjalan sebagaimana yang diharapkan. Kelihaian masa pemerintahan Orde Baru yang bertahan cukup lama adalah kemampuan menyuguhkan pemberitaan mengenai kebaikan tatanan kepemerintahan. Semua kekacauan yang terjadi hanya akan dilihat dan dirasakan oleh kaum terlibat. Semua bentuk ketidakadilan, kejahatan, dan kekacauan yang terjadi sengaja ditutupi bagi mata rakyat Indonesia. Penyerangan, pembunuhan, pemberontakan terhadap pemerintah tidak ada yang boleh di beritakan oleh media cetak apapun. Apabila ada yang mencoba untuk melakukannya akan dibredel atau di ubah sesuai dengan keinginan pemerintah Orba.

Pada saat rezim orde baru runtuh, dan reformasi digaungkan dimana-mana, media massa juga mengalami perkembangan yang signifikan. Tidak ada lagi pembatasan dalam pemberitaan. Para awak media diberi kebebasan dalam menyampaikan pemberitaannya, termasuk dalam pemberitaan terorisme. Tidak ada lagi yang ditutupi dalam memberitakan kejadian dan aksi terorisme yang terjadi di Indonesia. berdasarkan asumsi ini kemudian artikel ini lahir dari sebuah penelitian dan pengamatan yang cukup panjang.

\section{METODE}

Artikel ini dapat dikategorikan ke dalam jenis penelitian yang menggunakan studi literatur, dengan mencari referensi teori yang relevan dengan kasus atau permasalahan yang ditemukan. Referensi teori yang diperoleh dengan jalan penelitian studi literatur dijadikan sebagai pondasi dasar dan alat utama bagi praktek penelitian di tengah lapangan. Menurut Burhan Bungin, metode literatur adalah salah satu metode pengumpulan data yang digunakan dalam metodologi penelitian sosial untuk menelusuri data historis. Sementara Sugiyono menyatakan bahwa literatur merupakan catatan peristiwa yang sudah berlalu yang berbentuk tulisan, gambar, atau karya-karya monumental dari seseorang. Mengingat penelitian ini menitikberatkan pada permasalahan pemberitaan terorisme pada media cetak dari masa kolonial Belanda sampai pasca reformasi, maka bahan utama penelitian menggunakan dokumendokumen dari surat kabar, majalah, media online tentang isi pemberitaan terorisme yang telah terjadi. Selain itu juga akan dibahas mengenai perkembangan dari media massa itu sendiri, yang akan dilihat dari dokumentasi perkembangan dari masa Kolonial Belanda sampai Pasca reformasi.

Sedangkan pendekatan analisis yang digunakan adalah pendekatan gabungan antara analisis naratif dan analisis historis. Artikel ini menggunakan gabungan pendekatan naratif dengan pendekatan historis. Kecenderungan penelitian ini adalah historis, yang dicampur dengan narasi-narasi yang dibangun oleh tokoh yang menjadi sumber informasi, dalam melihat perkembangan media massa melakukan pemberitaan terorisme dari masa penjajahan Belanda hingga masa reformasi hari ini. 
Analisis naratif adalah analisis mengenai narasi, baik narasi fiksi (novel, cerita rakyat, dongeng, puisi, film, komik, musik, dan sebagainya) ataupun fakta seperti berita. Menggunakan analisis naratif berarti menempatkan teks sebagai sebuah cerita. Teks dilihat sebagai rangkaian peristiwa, logika, bagian dari peristiwa yang dipilih, tata urutan peristiwa. Analisis naratif memiliki sejumlah kelebihan. Pertama, analisis naratif membantu memahami bagaimana pengetahuan, makna, dan nilai diproduksi, dan disebarkan dalam masyarakat. Kedua, memahami bagaimana dunia sosial dan politik diceritakan dalam pandangan tertentu yang dapat membantu untuk mengetahui kekuatan dan nilai sosial yang dominan di masyarakat. Ketiga, analisis naratif memungkinkan untuk menyelidiki hal-hal yang tersembunyi dan laten dari suatu teks media. Keempat, analisis naratif merefleksikan kontinuitas dan perubahan komunikasi (Eriyanto, 2013:10-11). Melalui analisis naratif ini, dapat memudahkan untuk menganalisa bagaimana perubahan narasi dapat menjadi gambaran perubahan nilai-nilai yang ada dalam masyarakat. Pada dasarnya analisis naratif menempatkan teks berita media tidak ubahnya seperti novel, film, atau cerpen. Sebagai salah satu metode analisis teks berita media, analisis naratif mempunyai kelebihan, yaitu makna tersembunyi dari suatu pemberitaan akan dapat terlihat dengan jelas, melalui nalar dan logika dan pembuat berita ketika mengangkat suatu realitas kedalam teks berita. Analisis naratif memberikan panduan bagaimana peristiwa diceritakan, dan bagaimana aktor yang diberitakan oleh media ditempatkan dalam karakter penokohan. Lebih jauh lagi lewat analisis naratif kita bisa mengetahui nilai-nilai dominan, ideologi, dan perubahan yang ada dalam masyarakat. Dalam pemberitaan mengenai terorisme, dengan menggunakan analisis naratif tersebut dapat dilihat bagaimana telah terjadi pergeseran dalam metode penyampaian terorisme bagi kalangan media, sehingga tidak dapat disangkal bahwa pemberitaan tersebut menimbulkan efek bagi khalayak ramai.

Sedangkan analisis historis adalah bertumpu pada tujuan untuk merekontruksi masa lampau secara sistematis dan objektif, dengan cara mengumpulkan, mengevaluasi, memverifikasi, serta menghubungkan bukti-bukti untuk mengungkap fakta dan memperoleh kesimpulan yang kuat. Penelitian ini mempunyai ciri-ciri tertentu, diantaranya data yang dikumpulkan tidak hanya primer (yang diperoleh dari sumber primer, yaitu hasil observasi, atau wawancara peneliti sendiri), melainkan juga sekunder yang diperoleh dari sumber sekunder, yaitu hasil observasi orang lain. Untuk menentukan bobot data, dilakukan dua macam kritik, yaitu (1) eksternal: meneliti keaslian atau authenticity data, dan (2) internal: meneliti keakuratan atau kebenaran data.

Dalam melakukan penelitian, penulis menggunakan beberapa jenis dan sumber data yang nantinya akan diolah untuk kepentingan penelitian ini. Jenis data pada penelitian ini menggunakan jenis data kualitatif. Sedangkan sumber data utama dalam penelitian kualitatif ini berupa berita mengenai terorisme yang diterbitkan dalam surat kabar pada masa kolonial dan pada masa reformasi hingga hari ini. Selain itu juga 
terdapat data wawancara dengan informan yang memiliki kompetensi dalam bidang pengamatan terorisme di Indonesia. Selebihnya berupa data tambahan seperti dokumen dan buku-buku yang terkait. Jenis data kualitatif diungkapkan dalam bentuk kalimat dan uraian-uraian, bahkan dapat menunjukkan perbedaan dalam bentuk jenjang atau tingkatan, walaupun tidak jelas batas-batasnya.

\section{HASIL DAN DISKUSI}

\section{Perkembangan Media Massa Di Indonesia}

Sejarah Indonesia dapat dibagi ke dalam beberapa periode yaitu;
a. Periode Kolonial Belanda
b. Periode Pendudukan Jepang
c. Periode awal kemerdekaan hingga orde lama
d. Periode Orde Baru
e. Periode Reformasi hingga sekarang

Pada berbagai periode ini, media massa telah berkembang dengan caranya sendiri. Misalnya pada masa kolonial Belanda, Dalam sejarah tercatat bahwa koran yang terbit pertama di masa penjajahan bangsa Belanda adalah Bataviasche Nouvelles en politique Rasionementen atau yang lebih dikenal dengan nama Bataviasche Nouvelles saja.

Dalam Ensiklopedi yang dituliskan Diskominfo DKI Jakarta, (https://jakarta.go.id/artikel/konten/2670/bataviasche-nouvelles, diakses 15 April 2020) tercatat, Bataviasche Nouvelles merupakan lembaran berita Batavia yang digagas Gubernur Jenderal van Imhoff. Bataviase Nouvelles berhenti beredar sejak tahun 1746 atas perintah para direktur VOC yang cemas melihat pers berkembang di Hindia Belanda. Namun tidak lama kemudian surat kabar ini kembali beredar. Pada masa pemerintahan Gubernur Jendral Daendels, ia memberlakukan peraturan khusus yang berisi 19 pasal untuk menarik pajak dan mewajibkan redaktur Bataviaasche Nouvelles untuk menempatkan kepentingan pemerintah, sehingga ia kemudian mengganti Bataviaasche Nouvelles menjadi Bataviaasche Koloniale Courant.

Pada masa berikutnya, pers Indonesia mulai tumbuh dan berkembang seiring dengan zaman pergerakan nasional pada akhir abad 19-an. Surat kabar Medan Prijaji adalah pelopor pers nasional Indonesia. Surat kabar ini terbit pada tahun 1907 dan merupakan surat kabar mingguan. Pemimpin Redaksinya adalah RM Tirto Adhi Soerjo. Surat kabar ini merupakan suara golongan priyayi. Setelah kemerdekaan Indonesia, surat kabar milik Indoensia juga berkembang dengan sangat pesat. Saat itu terbit majalah Pantja Raya kemudian disusul majalah dan surat kabar lain diantaranya, Pembangoenan (Sutan Takdir Alisyahbana), Siasat, Pedoman. Mimbar Indonesia. Di daerah selain Jakarta juga terbit koran diantaranya: Menara Merdeka (Ternate), Soeara 
Indonesia, Pedoman (Makasar), Soeara Merdeka (Bandung), Soeara Rakjat (Surabaya), Kedaulatan Rakyat, Nasional (Yogyakarta). Soeloeh Rakyat (Semarang), Pewarta Deli, Suluh Merdeka, Mimbar Umum (Sumatera Utara), Sumatera Baru (Palembang), Pedoman Kita, Demokrasi, Oetosan Soematera (Padang), Semangat Merdeka (Aceh). Ketika ibukota Republik Indonesia di Yogyakarta para pewarta surat kabar dan majalah kemudian mengadakan pertemuan di gedung Sociteit atau Sasono Suko Solo pada tanggal 9 Februari 1946, dan membentuk Persatuan Wartawan Indonesia (PWI). Gedung tempat pertemuan tersebut dilangsungkan, saat ini dijadikan sebagai Monumen Pers Nasional. PWI merupakan organisasi profesi wartawan pertama setelah diproklamasikannya kemerdekaan Indonesia dengan Ketua Mr. R.M Sumanang Suryowinoto. Dan empat bulan kemudian tepatnya 8 Juni 1946 berdiri Serikat Perusahaan Surat Kabar (SPS) di Yogyakarta. Hal ini makin memperkokoh peran pers di awal berdirinya negara Indonesia.

Setelah Medan Prijaji, tercatat masih ada surat kabar lainnya yang terbit. Di Jakarta terbit Taman Sari menjelang abad-20 pimpinan F Wiggers. Lalu ada Pemberita Betawi pimpinan J.Hendrik. Sedangkan di Kota Bandung terbit Pewarta Hindia dipimpin oleh Raden Ngabehi TA sejak 1894. Di Kota Semarang juga terbit Surat Kabar Bintang Pagi dan Sinar Djawa. Surat kabar terus berkembang hingga pemerintahan orde lama pimpinan Soekarno runtuh akibat adanya gerakan separatis orang komunis di Indonesia. Pada tahun 1967, orde lama runtuh dan digantikan oleh orde baru yang lebih militeristik. Pada saat ini, pemerintah menerapkan kontrol yang ketat dalam pemberitaan media apapun, baik surat kabar, radio, maupun televisi. Peranan awak media tidak menjadi begitu penting pada masa ini. Mereka bahkan tidak leluasa melakukan pekerjaannya, karena semua telah dikontrol oleh pemerintah. Melihat situasi ini, beberapa awak media dan medianya mencoba untuk melenceng dari peraturan yang dibuat oleh pemerintah. Mereka mencoba membocorkan beberapa kejanggalan pemerintahan dalam menjalani kepemimpinan orde baru. Keberanian tersebut pada akhirnya berbuah pembredelan dan pencabutan ijin terbit oleh pemerintah.

Situasi baru kembali kondusif ketika rezim orde baru runtuh pada tahun 1998. Indonesia memasuki pembabakan reformasi. Dalam babak ini, media mendapat angin yang begitu segar dalam memberitakan apa saja. Tidak lagi ada kontrol ketat dari pemerintah. pada periode ini, media massa benar-benar hadir dalam fungsinya sebagai media penyampai informasi kepada masyarakat. Berikut ini tabel mengenai perkembangan media massa yang ada di indonesia sejak masa kolonial Belanda hingga reformasi.

Tabel 1.

Perkembangan Media Massa

\begin{tabular}{|l|l|l|}
\hline Nama & Jenis Media Massa & Bentuk Perkembangannya \\
\hline $\begin{array}{l}\text { Masa Kolonial } \\
\text { Belanda }\end{array}$ & Surat kabar & Awal terbentuk berupa sarana iklan atau \\
\hline
\end{tabular}




\begin{tabular}{|l|l|l|}
\hline & & $\begin{array}{l}\text { untuk sektor perdagangan. } \\
\text { Berkembang hingga menjadi sarana } \\
\text { pemerintahan untuk sosial politik dan } \\
\text { sebagai pemersatu bangsa Indonesia dalam } \\
\text { membentuk nasionalisme untuk meraih } \\
\text { kemerdekaan }\end{array}$ \\
\hline $\begin{array}{l}\text { Masa } \\
\text { Jenjajahan }\end{array}$ & Surat Kabar & $\begin{array}{l}\text { Perkembangan tidak terlihat, hanya pada } \\
\text { sisitem penerbitan lebih diperketat, dan isi } \\
\text { pemberitaan hanya seputar kabar jepang } \\
\text { Awajal }\end{array}$ \\
\hline Kemerdekaan & Surat Kabar & $\begin{array}{l}\text { Pemberitaan seputar kemerdekaan } \\
\text { Indonesia, dan masih dalam tahap } \\
\text { pembatasan dalam pemberitaan. }\end{array}$ \\
\hline Masa Orde Baru & Surat Kabar & $\begin{array}{l}\text { Tidak ada perkembangan, seakan mati, } \\
\text { karena terlalu banyaknya aturan dan } \\
\text { pembrendelan }\end{array}$ \\
\hline $\begin{array}{l}\text { Masa Reformasi } \\
\text { sampai sekarang }\end{array}$ & Surat Kabar & $\begin{array}{l}\text { Kebebasan dalam bersuara dan } \\
\text { berpendapat, memiliki banyak perubahan } \\
\text { dalam pemberitaan yang lebih terbuka dan } \\
\text { tidak adanya pemberedelan dalam isi } \\
\text { kritikan terhadap apapun walaupun itu } \\
\text { mengritik sistem pemerintahan. Akses yang } \\
\text { mudah didapatkan karena bentuk dari media } \\
\text { massa sendiri sudah banyak dan sangat } \\
\text { berkembang. }\end{array}$ \\
\hline
\end{tabular}

\section{Perkembangan Konsepsi Terorisme di Indonesia}

Hingga saat ini, pengertian dan definisi tentang terorisme masih menjadi perdebatan, meskipun sudah ada ahli yang merumuskan dan juga dirumuskan di dalam peraturan perundang-undangan. Akan tetapi, ketiadaan definisi hukum internasional mengenai terorisme tersebut tidak serta-merta meniadakan definisi hukum terorisme itu sendiri. Masing-masing negara mendefinisikan menurut hukum nasionalnya untuk mengatur, mencegah dan menanggulangi terorisme. Kata "teroris" (pelaku) dan terorisme (aksi) berasal dari kata latin "terrere" yang berarti gemetaran dan "detererre" yang berarti takut. Kata teror juga bisa menimbulkan kengerian (Wahid, 2004:22). Gemetaran, takut dan semua pengertian kengerian tersebut ditujukan untuk korban dari aksi terorisme. Namun, pada dasarnya istilah terorisme adalah sebuah konsep yang memiliki konotasi yang sangat sensitive, karena terorisme menyebabkan terjadinya pembunuhan dan penyengsaraan terhadap orang-orang tidak berdosa. Kamus besar bahasa Indonesia menyebutkan bahwa, terorisme adalah penggunaan kekerasan atau 
ancaman untuk menurunkan semangat, menakut-nakuti, dan menakutkan, terutama untuk tujuan politik. (KBBI, 2009:1455).

Pengertian terorisme untuk pertama kali dibahas dalam European Convention On The Suppression Of Terrorism (ECST) di eropa tahun 1977 terjadi perluasan paradigma arti dari Crimes Against State menjadi Crimes Againt Humanity. Crimes Againt Humanity meliputi tindak pidana untuk menciptakan suatu keadaan yang mengakibatkan individu, golongan, dan masyarakat umum ada dalam suasana teror. (KBBI, 2009:1455). Dalam kaitannya dengan HAM, Crimes Againt Humanity masuk ke dalam kategori Gross Violation Of Human Rights. Maksudnya di sini adalah bahwa serangan yang dilakukan dalam aksi terorisme merupakan bagian serangan yang meluas atau sistematik. Serangan yang dilakukan bahkan tidak melihat kepada siapa serangan itu ditujukan atau dengan istilah random. Kebanyakan korban dari serangan terorisme adalah korban yang tidak berdosa atau masyarakat sipil.

Teroris juga mempunyai arti yang lebih spesifik seperti yang dikemukakan dalam the arab convention on the supression of terorism (1998). Di sini terorisme diartikan sebagai tindakan atau ancaman kekerasan, apapun motif dan tujuannya, yang terjadi untuk menjalankan agenda tindak kejahatan individu atau koletif, yang menyebabkan terror di tengah masyarakat, rasa takut dengan melukai mereka, atau mengancam kehidupan, kebebasan, atau keselamatan, atau bertujuan untuk menyebabkan kerusakan lingkungan atau harta public maupun pribadi atau menguasai dan merampasnya atau bertujuan untuk mengancam sumber daya nasional. (Muladi, 2002:25). Dalam Pasal 1 Perpu No. 01 Tahun 2002 Tentang Pemberantasan Tindak Pidana Terorisme (sekarang sudah disahkan menjadi Undang-Undang Nomor 15 Tahun 2003 Tentang Pemberantasan Tindak Pidana Terorisme) disebutkan, Terorisme adalah perbuatan melawan hukum secara sistematis dengan maksud untuk menghancurkan kedaulatan bangsa dan Negara dengan membahayakan bagi badan, nyawa, moral, harta benda dan kemerdekaan orang atau menimbulkan kerusakan umum atau suasana teror atau rasa takut terhadap orang secara meluas, sehingga terjadi kehancuran terhadap objekobjek vital yang strategis, kebutuhan pokok rakyat, lingkungan hidup, moral, peradaban, rahasia negara, kebudayaan, pendidikan, perekonomian, teknologi, perindustrian, fasilitas umum, atau fasilitas nasional.

Terorisme telah muncul pada akhir abad 19 dan menjelang terjadinya Perang Dunia (PD) I. Tidak hanya di Eropa, teroris muncul di berbagai wilayah di belahan dunia. Sejarah mencatat pada tahun 1890-an aksi terorisme Armenia melawan pemerintah Turki, yang berakhir dengan bencana pembunuhan massal terhadap warga Armenia pada PD I. Pada dekade PD I, aksi terorisme diidentikkan sebagai bagian dari gerakan sayap kiri yang berbasiskan ideologi. Ketika Perang Dunia II terjadi pada pertengahan abad 20, situasi menjadi tidak terkendali lagi. Walaupun perang dunia berakhir, namun dunia tidak lagi pernah mengenal "damai". Berbagai pergolakan, konflik, bentrokan, kekerasan berkembang dan berlangsung secara berkelanjutan. Konfrontasi negara adikuasa yang meluas menjadi konflik Timur-Barat dan menyeret beberapa negara Dunia Ketiga ke dalamnya, menyebabkan timbulnya konflik Utara- 
Selatan. Perjuangan melawan penjajah, pergolakan rasial, konflik regional yang menarik campur tangan pihak ketiga, pergolakan dalam negeri di sekian banyak negara Dunia Ketiga, membuat dunia labil dan bergejolak. Ketidakstabilan dunia dan rasa frustasi dari banyak negara berkembang dalam perjuangan menuntut hak-hak yang dianggap fundamental dan sah, membuka peluang muncul dan meluasnya terorisme. Hingga hari ini, terorisme terus berkembang terutama di Indonesia. perbedaan ideologi yang dibarengi dengan perbedaan pemahaman agama membuat konflik sosial dan aksi teror terus berlanjut. Dalam menimbulkan teror, para teroris juga kerap menggunakan media untuk menyebarkan ketakutan terhadap mereka. Salah seorang pengamat terorisme, Al Chaidar Abdul Rahman bahkan menyebutkan bahwa memang terdapat beberapa media yang sering dgunakan oleh kalangan teroris.

"kaum teroris memang memanfaatkan media, namun hanya sebatas media yang mudah seperti media sosial Telegram, Facebook, Instagram, Whatshapp dan Twitter. Kaum teroris memanfaatkan media sosial karena mudah, murah dan sulit dilacak atau diketahui oleh pihak keamanan. Sulit bukan berarti tidak bisa dilacak. Kebanyakan teroris ditangkap karena masalah media sosialnya yang dapat dilacak oleh pihak kepolisian. Sedangkan media konvensional seperti, radio, televisi, majalah, atau koran dan tabloid tidak bisa dipergunakan oleh kaum teroris karena media tersebut bersifat permanen-base bukan media yang bisa dikelola secara gampang, mobile dan berpindah-pindah."

Setelah era reformasi dimulai, Indonesia sudah mengalami aksi terorisme selama beberapa kali. Ratusan jiwa tewas dan lebih banyak lagi korban luka di Indonesia akibat aksi terorisme. Tahun 2001 bom meledak di Bali, disusul serangan bom di Hotel J.W Marriot pada tahun 2003. Kedutaan Australia di Jakarta tak luput dari serangan bom teroris pada tahun 2004. Tahun 2005 Bali mengalami serangan bom dari teroris untuk kedua kalinya. Hotel J.W Marriot dan Ritz-Carlton pada tahun 2009 juga menjadi sasaran bom dari teroris. Menurut narasumber tentang terorisme pada saat sekarang yaitu:

"kondisi terorisme di Indonesia saat ini sangat serius, pihak keamanan (densus 88 polri) sangat serius dalam menghadapi perkembangan terorisme di Indonesia. Perkembangan modus dan semakin banyaknya pengikut kelompok-kelompok terorisme sangat mengkhawatirkan. Indonesia adalah negara yang sulit lepas dari terorisme meskipun Indonesia memiliki datasemen khusus anti teror yang sangat cerdas dalam mengatasi terorisme yang semakin hari semakin cerdas. Gerakan terorisme sekarang ini terdiri dari banyak kelompok teroris. Ada JAD, $J A K, J A D-K N$, MIT dan lain-lain yang semuanya sangat berkembang dalam hal jumlah pengikut yang semakin besar". 
Dari sumber yang telah diperoleh, bahwa aksi-aksi terorisme pada saat sekarang sangatlah banyak dan lebih menakutkan, karena mereka sudah memiliki banyaknya anggota dan banyaknya kelompok-kelompok dalam membentuk suatu gerakan teror. Seperti dapat kita lihat dari aksi terbaru dari kasus terorisme di negara kita adalah teror yang terjadi di Sarinah. Peristiwa Bom Thamrin pada tanggal 14 Januari 2016 itus angat mengejutkan bangsa Indonesia. Hal ini dikarenakan peristiwa ini ternyata didalangi oleh kelompok militan ISIS yang pada akhir tahun sebelumnya melancarkan serangan di Paris Prancis, seperti di beritakan pada laporan utama majalah Tempo edisi 18-24 Januari 2016 dengan judul "Konser"e Paris Di Sarinah". Pada laporan utama ini, Majalah Tempo mengilustrasikan dengan detail bagaimana para pelaku teroris melancarkan aksinya di sekitaran J1.M.H. Thamrin seperti serangan yang dilancarkan para pelaku bom Paris. Para pelaku teroris meledakkan pos polisi lalu menembakkan pistol ke arah kerumunan yang tengah menyaksikan meledaknya pos polisi sebelumnya. Selain itu juga ditemukan berbagai barang bukti yang digunakan oleh para pelaku dalam melancarkan aksinya.

\section{Gambar 1}

Pemberitaan Media cetak
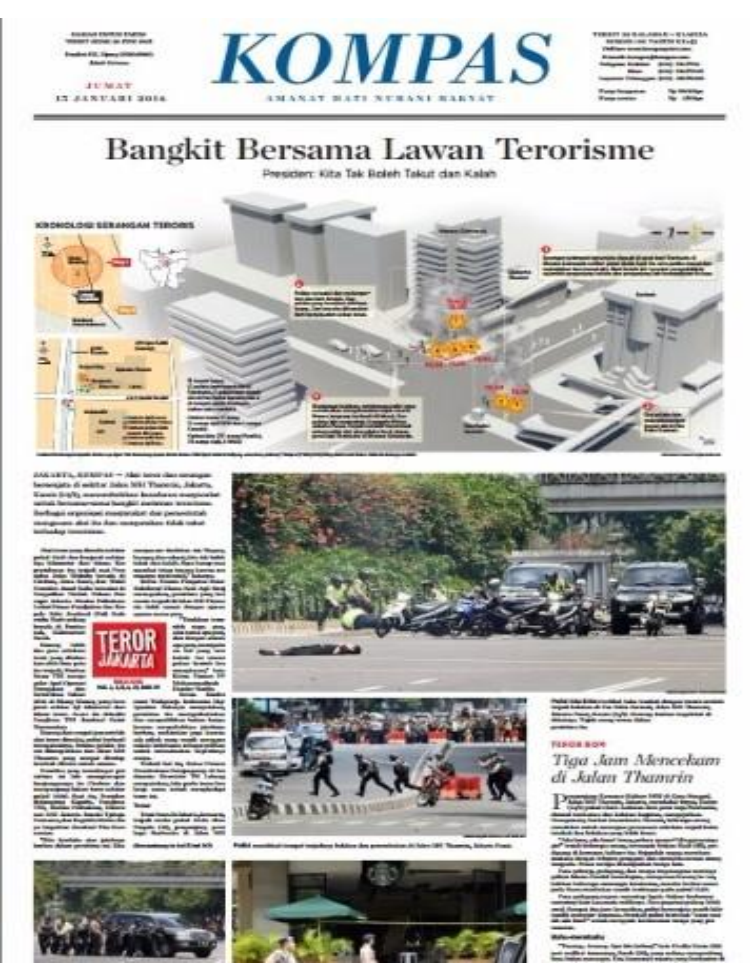

Semua pemberitaan aksi terorisme yang telah terjadi merupakan bentuk perkembangan dari media massa sebagai sarana informasi bagi rakyat untuk mengetahui semua yang telah terjadi di negara dan belahan dunia. Pemberitaan seakan menjadi makanan umum yang sering kali dilihat dan dipertontonkan. Media cetak tidak luput dari semua pemberi berita tentang terorisme, baik media cetak lokal maupun nasional 
bahkan internasional. Semua akan terpampang jelas dan seakan fakta bahwa kejadian tersebut menjadi peristiwa mengejikan, menjadi tontonan mengerikan dan menakutkan, bagaimana kekacauan yang terjadi digambarkan sangatlah baik.

\section{Isu Terorisme Dalam Media Massa Pada Masa Kolonial di Indonesia}

Belanda telah menggolongkan beberapa peristiwa yang dilakukan kelompok pribumi sebagai aksi terorisme. Misalnya saja kasus Pemberontakan komunisme pada tahun 1927-1928, perlawanan pada perang kemerdekaan 1945, dan perlawanan pada masa revolusi ketika Belanda bersama sekutu kembali untuk mengembalikan kedudukan mereka sebagai pemerintah kolonial di Indonesia. Dalam sudut pandang kolonial, teroris tentu saja orang-orang pribumi yang berseberangan dengannya, dan sebaliknya, dalam sudut pandang masyarakat, orang-orang yang diklasifikasikan teroris oleh pemerintah kolonial adalah pahlawan di mata mereka. Dalam pembahasan ini, menggunakan sudut pandang pemerintah kolonial, karena media massa berupa koran pada masa kolonial Belanda.

Satu hal yang cukup menarik dalam perkembangan media massa pada zaman kolonial dalam menyikapi persoalan terorisme adalah bahwa, media massa kemudian muncul untuk meminimalisir dampak dari terorisme dan perang. Sepanjang perjalanan praktek kolonialisme di Indonesia, telah terjadi banyak sekali perperangan antara pemerintah kolonial dengan masyarakat pribumi, kelompok ekstrimis, maupun pemberontak. Uniknya, berita-berita mengenai aksi terorisme yang terjadi benar-benar disaring oleh pemerintah kolonial untuk dikabarkan pada media massa. Dampak buruk dari perang dan kerusuhan yang terjadi tidak diberitakan dengan gamblang, namun hanya tersirat saja. Jumlah korban bahkan tidak disebutkan sama sekali. Hal ini bertujuan untuk meredam efek dari perang dan kerusuhan yang terjadi tersebut, sehingga masyarakat Eropa dan pribumi, yang berada di luar wilayah terjadinya perang dan kerusuhan, tidak terlalu merasakan efek dari perang tersebut.

Misalnya dalam surat kabar De Sumatera Post, terbitan 11 Mei 1928 yang berisikan berita mengenai penangkapan ekstrimis yang melakukan aksi teror pasca pemberontakan Silungkang Sumatera Barat pada tahun 1927. Dalam buku karangan Audrey Kahin, "Dari Pemberontakan Ke Integrasi", digambarkan mengenai alotnya pertempuran yang terjadi antara pemerintah kolonial dengan pemberontak pada saat itu. Banyak orang yang terbunuh dalam aksi tersebut. Namun, dalam serangkaian pemberitaan mengenai itu, aksi yang terjadi tidak terlihat menakutkan dan berbahaya. 
Gambar 2

Surat kabar Sumatra Post 11 Mei 1928

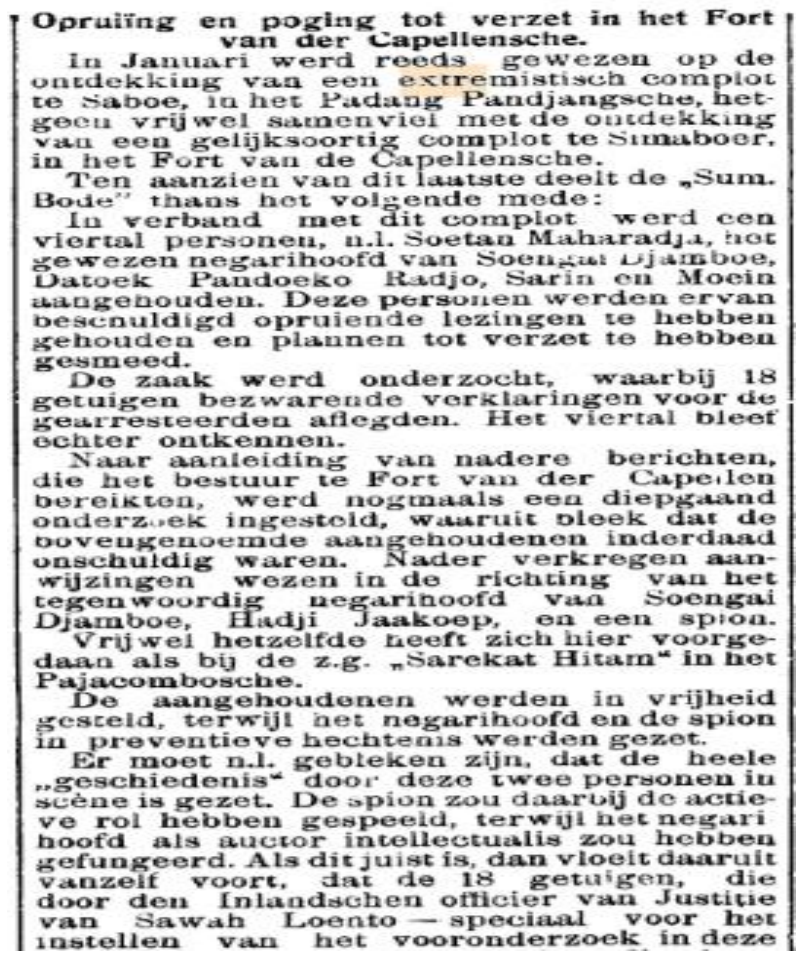

Dalam koran tersebut pemerintah kolonial membuat sebuah pemberitaan mengenai aksi gerakan ekstrimis yang kira-kira pengertiannya adalah,

"Peristiwa penghasutan dan perlawanan di Fort van der Capellensche. Pada bulan Januari, ditemukan titik ekstremis di Saboe, Padangpanjang, yang hampir bertepatan dengan penemuan titik serupa di Simaboer, di Capellen (Batusangkar). Berkenaan dengan itu, Herald juga melaporkan: Sehubungan dengan konspirasi ini, empat orang ditangkap, yaitu Soetan Maharadja, mantan kepala Negari Sungai jamboe, Datuk Panduko Radjo, Sarin dan Moein. Kasus ini diselidiki, dengan 18 saksi yang membuat pernyataan untuk mereka yang ditangkap, tetapi keempatnya terus menyangkalnya. Setelah laporan lebih lanjut, yang mencapai dewan di Fort van der Capellen, penyelidikan lebih lanjut dilakukan, yang menunjukkan bahwa tahanan yang disebutkan di atas memang tidak bersalah. Bukti lebih lanjut diperoleh yang menunjuk kepala Negari Sungai Djambu saat ini, Hadji Jaakoep, mengenai mata-mata. Di sini hampir sama terjadi dengan apa yang disebut "Sarekat Hitam" di Pajacombosche. Para tahanan dibebaskan, sementara kepala mata-mata ditempatkan di tempat penahanan. Mata-mata akan memainkan peran aktif dalam hal ini, sedangkan kepala Nagari akan bertindak sebagai aktor intelektual. Jika ini benar, 18 saksi dari Jaksa Penuntut Indische (pribumi) tentang Sawah Loento (Pemberontakan Silungkang) - terutama untuk memulai penyelidikan awal dalam kasus ini yang telah diperbantukan ke Simabur selama beberapa waktu - tentu saja ditanyai dan membuat pernyataan palsu (mungkin "diinstruksikan"), kabarnya, antara lain, bahwa "pengacau" akan mengadakan 
pertemuan di sebuah rumah di atas bukit. Penelitian lebih lanjut menunjukkan bahwa rumah ini runtuh saat gempa Juni 1926. Sebelumnya, rumah ini hanya berisi beberapa pohon."

Berita di atas berisi tentang bagaimana pemerintah melakukan penangkapan terhadap beberapa orang ekstrimis yang dinilai melakukan aksi teror pasca terjadinya pemberontakan Silungkang Sumatra Barat pada tahun 1927. Dalam berita tersebut terlihat bahwa pemerintah kolonial benar-benar membendung pemberitaan yang terkait dengan pemberontakan yang terjadi.

Berita lain seperti aksi teror yang dilancarakan DI/TII Jawa Barat yang dilaporkan dalam Het Nieuwsblad voor Sumatra pada 14 April 1955, dimana koran ini tidak memberitakan siapa dan untuk apa gerombolan tersebut melakukan aksinya. Sementara itu, di dalam laporan operasi militer dalam buku yang dibuat Dinas Penerangan TNI yang berjudul "Sejarah TNI-AD 1950-1972", aksi yang sama persis seperti di dalam berita tersebut dilancarkan oleh anggota DI/TII, sebuah gerakann ekstrimis Islam yang dilakukan Kartosuwiryo di daerah Jawa Barat.

Hal yang sama juga berlaku dalam pemberitaan aksi teror pada masa revolusi. Dalam laporan surat kabar De Vrije Pers dan De Volksrant pada Februari 1946, setelah orang Eropa dan sebagian orang Indo-Eropa dipindahkan dari Pekanbaru ke Padang untuk kemudian dievakuasi ke Batavia, bangsa Tionghoa, India dan pribumi yang menjadi sasaran kekerasan, menyurati komandan pasukan Belanda saat itu yang berada di Padang, Sumatera Barat, untuk meminta bantuan, karena telah terjadi aksi teror oleh kelompok bersenjata yang mengaku dirinya kelompok republikeun di wilayah kediaman mereka.

Pemberitaan yang beredar di dua surat kabar tersebut hanya sebatas itu saja, padahal menurut laporan NEFIS, lembaga intelijen Belanda saat itu, terjadi aksi teror yang mengerikan di beberapa wilayah hunian Tionghoa tersebut. Kelompok tersebut menjarah semua barang yang mereka miliki secara paksa dan dengan kekerasan. Perempuan bahkan diculik untuk diperkosa dan kemudian dibunuh. Di wilayah Jambi tidak jauh berbeda. Setelah orang Eropa selesai dievakuasi ke Padang dan Palembang pada tahun 1946, terjadi teror mengerikan terhadap sisa orang Indo-Eropa, orang Tionghoa, India dan masyarakat pribumi. Pemukiman masyarakat yang berada di satu wilayah dengan orang Eropa, dan merupakan distrik bisnis di Jambi kemudian dibakar oleh kelompok pejuang revolusi yang pada saat itu terdiri dari orang komunis dan tentara berseragam. Lebih dari $2 / 3$ wilayah sentra bisnis tersebut hangus dibakar. Hunian orang Eropa, Tionghoa, India dan masyarakat lokal hancur total. Sekitar 7000 orang Tionghoa, 500 orang India, dan puluhan masyarakat lokal kehilangan tempat tinggal. 


\section{Isu Terorisme Dalam Media Massa Setelah Indonesia Merdeka}

Sementara itu, dalam pemerintahan Indonesia hari ini justru kita dapat melihat bahwa media massa saat ini seolah-olah terbagi menjadi dua fungsi, sebagai pelindung bagi para pejabat pemerintahan, dan sebagai penyebar propaganda. Hal ini dapat dilihat dari berbagai kasus yang terjadi saat ini, dimana ketika ada pejabat pemerintahan yang bermasalah justru berita yang ditampilkan di televisi maupun koran tidak menyorot peristiwa apa yang terjadi, melainkan seringkali menyorot hal lain yang kurang penting atau tidak berhubungan dengan permasalahan pejabat pemerintahan tersebut. Dengan kata lain media hari ini sebagai pengalihan isu-isu yang berkembang di tubuh pemerintahan, yang cenderung tidak netral dalam menyebarkan pemberitaan, dan hadir sebagai bentuk tendensi penguasa atau pemerintah. Selain itu, media juga muncul menjadi senjata ampuh untuk menyebarkan isu-isu sensitif seperti isu SARA yang sangat mudah menyalakan amarah rakyat.

Penggunaan media massa oleh gerakan-gerakan radikal sebenarnya memang bukanlah fenomena baru, namun peristiwa 11 september 2001 lalu memunculkan kembali isu radikalisme atau terrorism based on religion dan gaungnya masih menjadi isu kontroversial dan sentral dalam bidang keamanan dunia. Kontroversi Al-Qaeda dan gerakan-gerakan Islam radikal lainnya yang menyuarakan simbol-simbol Islam yang mereka bawa secara langsung berdampak pada kaum muslim global dan mempengaruhi peta konflik dunia. Bahkan belakangan ini isu-isu radikalisme Islam kembali mencuat dengan lahirnya ISIS yang dengan cepat mendunia dan menjadi topik global paska mereka meng-upload video sadis pembunuhan wartawan AS di Youtube. Pesan kengerian tersampaikan dengan cepat dan sekaligus menunjukkan eksistensi gerakan mereka.

Dalam pemberitaan mengenai terorisme, media hari ini bahkan sangat terbuka dalam memberitakannya. Bahkan penangkapan anggota terorisme yang di dalamnya memuat aksi tembak-menembak juga disiarkan secara langsung. Tidak hanya itu saja, aksi terorisme dalam bentuk pengeboman juga disiarkan secara langsung dan detail oleh media hari ini. Bahkan mayat korban juga dipertontonkan, walaupun diberi sedikit efek blur. Pada sebuah peristiwa yang menghebohkan tentang penyerangan terhadap mantan Menteri Politik, Hukum dan Keamanan (Menko Polhukam) Wiranto di Alun-alun Menes, Pandeglang, Banten pada tanggal 10 Oktober 2019 lalu, selama beberapa hari media hanya memberitakan mengenai penusukan ini saja, bahkan berbagai asumsi dan spekulasi bermunculan untuk menggiring opini masyarakat. Dengan demikian terlihat bahwa media massa yang dikendalikan oleh pemerintah adalah sumber utama lahirnya perpecahan-perpecahan serta penyebaran isu-isu sensitif. Dengan terbuka luasnya perkembangan pemberitaan mengenai terorisme, mempunyai efek buruk yang tidak bisa dihindarkan. Media kemudian menjadi sedikit kebablasan. Misalnya yang dilakukan oleh harian The Jakarta Post. 
Pada 3 Juli 2014 harian The Jakarta Post menampilkan karikatur mengenai ISIS. Karikatur yang juga pernah dimuat di media Mesir dan Thailand itu menjadi bermasalah karena di dalamnya terdapat simbol agama Islam. Beberapa hari setelah pemuatan tersebut, The Jakarta Post mendatangi Dewan Pers dan resmi meminta maaf karena karikatur tersebut menuai protes sejumlah pihak. Dewan Pers juga sudah menyatakan bahwa pemuatan karikatur tersebut hanya melanggar kode etik jurnalistik. Namun sejumlah organisasi Islam melaporkan PemimpinRedaksi The Jakarta Post Meidyatama Suryodiningrat ke polisi pada 11 Desember 2014, yang kemudian ditetapkan sebagai tersangka kasus dugaan penistaan agama.

Kejadian seperti ini seolah menggerus fungsi media massa yang sesungguhnya. Menurut Elvinaro dalam bukunya Komunikasi Massa: Suatu Pengantar, fungsi media massa bisa dibagi menjadi lima, yaitu; a) Pengawasan (surveillance), b) Penafsiran (Interpretation), c) Pertalian (Linkage), d) Penyebaran Nilai-Nilai (Transmission of Value), e) Hiburan (Entertainment) (Ardianto 2007: 14-17). Media massa seharusnya hadir berdasarkan fungsinya tersebut. Namun pada kenyataannya tidak seperti itu. Herman dan Chomsky mengingatkan, media selalu berada dalam risiko untuk dimanipulasi dan digunakan oleh "kelompok-kelompok istimewa" yang lebih berkuasa dibanding kelompok lain dalam masyarakat. Sementara pihak yang lebih kuat mendapat banyak keuntungan, pihak yang lebih lemah kehilangan hak istimewanya sebagai kumpulan aktor aktif di ranah publik. Kepentingan masyarakat, terutama mereka yang lemah dan terpinggirkan, dibiarkan begitu saja karena aspirasi utama manipulasi ini adalah untuk memperta-hankan dominasi kekuasaan dalam masyarakat.

\section{KESIMPULAN}

Perkembangan media massa dari masa kolonial Belanda sampai sekarang cukup siknifikan dan berfariasi. Pada awal kolonial Belanda media massa berkembang dan pertama kali muncul di Indonesia yaitu media cetak. Dalam pemberitaan mengenai terorisme dan perang, pemerintah kolonial lebih selektif dan tertutup. Tidak semua hal mereka beritakan dengan gamblang. Hal ini bertujuan agar situasi tetap kondusif, sehingga efek aksi terorisme dan perang yang terjadi saat itu dapat diminimalisir. Perkembangan media cetak yang seperti itu bertahan sangat lama sampai masa kemerdekaan. Perkembangan yang telihat hanya dari segi isi dari surat kabar, yaitu awal munculnya sebagai sarana komunikasi dalam perdagangan, hingga berkembang menjadi saran sosial politik bagi pemerintahan. Kemudian pada masa orde baru media sempat mengalami kebuntuan, atau perkembangan sedikit tidak terlihat karena pada masa orde baru adalah masa kelam bagi media massa, karena masa orde baru adalah masa pembrendelan garis keras terhadap media massa. Masa kejayaan media massa atau media massa yang berkembang secara signifikan yaitu pada masa reformasi hingga saat sekarang. Perkembangan media masa pada masa ini terlihat dari media cetak, media elektronik hingga media online. Hanya saja dalam kasus pemberitaan terorisme dan 
konflik, media massa hari ini sangat terbuka dalam memberitakannya. Masyarakat bahkan bisa mengikuti kronologi pemberitaan seputar terorisme dan konflik yang terjadi.

\section{REFERENSI}

Abdul, Wahid. (2004) Kejahatan Terorisme

Perspektif Agama, HAM, dan Hukum.Bandung: PT Refika Aditama

Azra, Azyumardi, (2002) Jihad dan Terorisme, dalam Tabrani Sabirin, (ed), Menggugat Terorisme, Jakarta : CV. Karsa Rezeki

Baran, Stanley J. (2004). Introduction to Mass Communication: Media Literacy and Culture. New York: McGraw-Hill

Budi Winarno. (2007) Sistem Politik Indonesia Era Reformasi, (Yogyakarta: Media Pressindo

Grant Wardlaw, (1986) Political Terrorism, New York: Cambridge University Press

Hamad, Ibnu. (2004) Konstruksi Realitas Politik dan Media Massa. Jakarta

James M. Lutz dan Brenda J. Lutz, (2004) Global Terrorism, London: Routledge

Manullang, A.C, (2001) Menguak Tabu Intelijen Teror, Motif dan Rezim, Jakarta: Panta Rhei

Margianto, J. H dan Asep, S. (2012). Media Online: Pembaca, Laba, dan Etika Problematika Praktik Jurnalisme Online Indonesia. Jakarta: Aliansi Jurnlaisme Independent (AJI)

Salenda, Kasjim, (2009) Terorisme Dan Jihad Dalam Perspektif Hukum Islam, Jakarta: Badan Litbang Dan Diklat Departemen Agama RI

Taufik Rahzen, dkk.(2007) Seabad Pers Kebangsaan (1907-2007). Yogyakarta: I. Boekoe)

Vivian, John. (2008) Teori Komunikasi Massa (Edisi Kedelapan). Jakarta: Kencana https://jakarta.go.id/artikel/konten/2670/bataviasche-nouvelles, diakses 15 April 2020

Interview : Al Chaidar Abdul Rahman 